\title{
Assessment of Awareness and Practices with regard to Mosquito Borne Diseases in Rural Health Training Center, Guntur Medical College, Guntur
}

\author{
Dulla Chinnamma ${ }^{1}$, Ch. Harshitha², T. Divya Jyothi ${ }^{3}$ \\ ${ }^{1}$ Department of Community Medicine, Guntur Medical College, Guntur, Andhra Pradesh, India. ${ }^{2}$ Department of \\ Community Medicine, Guntur Medical College, Guntur, Andhra Pradesh, India. ${ }^{3}$ Department of Community Medicine, \\ Guntur Medical College, Guntur, Andhra Pradesh, India.
}

\section{ABSTRACT}

\section{BACKGROUND}

Vector borne diseases (VBD) account for more than $17 \%$ of all infectious diseases, causing more than 700000 deaths annually. VBDs constitute important cause of morbidity and mortality in India. Assessment of knowledge, attitude and practices of community about prevention of mosquito borne diseases is important for planning efficient interventions.

\section{METHODS}

This is a community based cross-sectional study conducted in Nidumukkala village Guntur Dist. from January 2019 to March 2019. 250 residents of Nidumukkala village, who were selected by systematic random sampling were included in the study. House to house survey was conducted, using preformed semi structured questionnaire, data was collected and analysed using SPSS version 16. Chi-square test was used to find the association and $\mathrm{p}<0.05$ was considered significant.

\section{RESULTS}

Among the 250 respondents, 136 (54\%) were females and 114 (46\%) were males. Nearly one third (33\%) of the heads of the families were illiterates. 137 (54.8\%) belong to upper lower class. Majority of them have knowledge regarding the vector breeding sites, symptoms of VBD. 50\% of them are using mosquito coils to prevent vector bites, $68 \%$ of them are not using any antilarval methods. $82.1 \%$ of them reported that 'Fogging' as the activity done by the government to control VBD, and nearly $85 \%$ responded that it is done irregularly.

\section{CONCLUSIONS}

There is a gap between the knowledge regarding VBD (Vector Borne Diseases) and practice of vector control among the respondents.

\section{KEY WORDS}

Vector Borne Diseases, Preventive Measures, Protective Methods

\author{
Corresponding Author: \\ Dulla Chinnamma, \\ Associate Professor \\ Department of Community Medicine, \\ Guntur Medical College, Guntur, \\ Andhra Pradesh, India \\ E-mail: chinnammadulla@gmail.com
}

DOI: $10.14260 / \mathrm{jemds} / 2019 / 726$

Financial or Other Competing Interests: None.

How to Cite This Article:

Chinnamma D, Harshitha C, Jyothi TD. Assessment of awareness and practices with regard to mosquito borne diseases in rural health training center, Guntur medical college, Guntur. J. Evolution Med. Dent. Sci. 2019;8(44):3347-3350, DOI: 10.14260/jemds/2019/726

Submission 08-05-2019,

Peer Review 16-10-2019,

Acceptance 23-10-2019,

Published 04-11-2019. 


\section{BACKGROUND}

Vector-borne infectious diseases are emerging or resurging as a result of changes in public health policy, insecticide and drug resistance, shift in emphasis from prevention to emergency response, demographic and societal changes, and genetic changes in pathogens. Effective prevention strategies can reverse this trend. Research on vaccines, environmentally safe insecticides, alternative approaches to vector control, and training programs for health-care workers are needed. Vector borne diseases (VBD) account for more than $17 \%$ of all infectious diseases, causing more than 700000 deaths annually.(1) VBDs constitute important cause of morbidity and mortality in India. In 2017 alone 0.53 million cases and 194 deaths noted due to malaria.(2) Effective reduction in the vector breeding sites combined with improved personal preventive strategies can significantly reduce the transmission of these diseases.(3) Previous studies have demonstrated the most effective vector control approaches used community-based methods tailored to the local context.(4-7) As mosquito is the commonest vector in India, the assessment of knowledge, attitude and practices of community about prevention of mosquito borne diseases is important for planning efficient interventions, therefore this study was conducted.

We wanted to determine the level of awareness, knowledge and practices towards vector borne diseases.

\section{METHODS}

A Cross sectional study was conducted in the Rural health training centre among 250 residents of Nidumukkala village, sample size was calculated considering $62 \%$ as level of knowledge regarding mosquito borne diseases according to a study done by Patel AB, Rathode, et al(3) with $95 \%$ confidence interval and $10 \%$ relative precision.

$\mathrm{N}=4 \mathrm{pq} / \mathrm{L}^{2}$

$=4(62)(100-62) /(6.2)^{2}$

$=4(62)(38) /(38)$

$=9424 / 38$

$=248$ which is rounded to 250

$\mathrm{N}=$ sample size, $\mathrm{P}=$ prevalence, $\mathrm{q}=(100-\mathrm{p}), \mathrm{l}=$ relative precision $(10 \%$ of $62 \%=6.2)$

\section{Methods of Data Collection}

The RHTC of Guntur medical college caters services for 8 villages, of those Nidumukkala village was selected by lottery method and through systematic random method total households (N) of the village were divided by 250 (n) to get $\mathrm{k}$ value as 5 and from the center of the village to the right side residents of every fifth house data was collected by interview method using pre formed semi structured questionnaire.

$\mathrm{k}=1150$

-------- $=4.6$ (rounded to 5)

250

\section{Statistical Analysis}

Data was collected and analyzed using SPSS version 16 . Chisquare test was used to find the association and $p<0.05$ was considered significant.

\section{RESULTS}

Among the 250 respondents 136 (54\%) are females and 114 $(46 \%)$ are males. Nearly one third $(33 \%)$ of Head of the family of them are illiterates. 137 (54.8\%) respondents belong to upper lower (according to Modified Kuppuswamy scale) socio economic status. Majority $(161,64.4 \%)$ of them are living in Pucca houses. $90 \%$ of the respondents lives in the areas with open Peridomestic drains. 38\% of them responded that Drains as the potential mosquito breeding sites followed by garbage (27\%). $44.8 \%$ of them knew that Mosquitos causes Malaria and $44.9 \%$ of them responded as Fever with chills as the common symptom associated with mosquito bites. $30.5 \%$ of them knew that keeping surroundings clean can prevent mosquito borne diseases (MBDs) (Table no. 1) Mosquito coils are most commonly used to prevent mosquito bites (50\%) (Table 2), nearly (68\%) of them are not using anti-larval measures (Table 3). Majority of them had relatives' friends and neighbours as source of information followed by TV and newspapers regarding MBDs (Fig. 1). Education of respondent is playing an important role in controlling mosquitos, presence of peri domestic drains and practice of vector control measures. People living with peri domestic drains are following more anti-larval measures than anti-adult measures compared to those living with closed drains and this is not statistically significant. Knowledge regarding MBDs is high among respondents whose head of the family were illiterates or completed primary education but Anti larval measures were practiced mostly by respondents whose head of the family had completed secondary education and above (Table 4) There is no significant difference between different socio economic classes and knowledge and practice of personal protective measures against mosquito bites but the anti-larval measures were taken by people belonging to upper lower social class (Table 5)

\begin{tabular}{|c|c|}
\hline Knowledge Regarding Mosquito Breeding Sites* & Frequency (\%) \\
\hline Drains & $176(38 \%)$ \\
\hline Garbage & $126(27 \%)$ \\
\hline Plants & $47(10.1 \%)$ \\
\hline Stagnant water & $42(9 \%)$ \\
\hline Others & $70(14.6 \%)$ \\
\hline Don't Know & $(1.3 \%)$ \\
\hline Malaria & \\
\hline Dengue & $207(44.8 \%)$ \\
\hline Chikungunya & $137(29.7 \%)$ \\
\hline Others & $65(14.1 \%)$ \\
\hline Don't know & $28(6 \%)$ \\
\hline Fever with chills & $25(5.4 \%)$ \\
\hline Headache & \\
\hline Vomiting & $193(44.9 \%)$ \\
\hline Body ache & $72(16.7 \%)$ \\
\hline Others & $45(10.5 \%)$ \\
\hline Don't know & $41(9.5 \%)$ \\
\hline Knowledge Regarding symptoms of MBD* & $50(11.0 \%)$ \\
\hline Regarding diseases caused by Mosquitos* & $29(6.7 \%)$ \\
\hline Knowledge Regarding Preventive measures against MBD* & \\
\hline Keeping surroundings clean & $132(30.5 \%)$ \\
\hline Spraying insecticides & $116(26.8 \%)$ \\
\hline Others & $80(18.5 \%)$ \\
\hline Don't Know & $78(18 \%)$ \\
\hline Table 1. Knowledge Regarding Mosquito Borne Diseases \\
\hline Responses are mutually not exclusive \\
\hline
\end{tabular}




\begin{tabular}{|c|c|}
\hline Type* & Frequency (\%) \\
\hline Mosquito coils & $173(50 \%)$ \\
\hline Bed nets & $80(23.2 \%)$ \\
\hline Liquid vapouriser & $44(12.8 \%)$ \\
\hline Screening doors and windows & $26(7.5 \%)$ \\
\hline Not using any method & $22(6.4 \%)$ \\
\hline Table 2. Personal Protective Measures taken to Prevent \\
Mosquito Borne Diseases \\
\hline *Responses are mutually not exclusive \\
\hline
\end{tabular}

\begin{tabular}{|c|c|}
\hline Type & Frequency (\%) \\
\hline Emptying of containers, change of water & $60(24 \%)$ \\
\hline Edible oil application & $20(8 \%)$ \\
\hline Not using any method & $170(68 \%)$ \\
\hline \multicolumn{2}{|c|}{ Table 3. Practice of Antilarval Measures } \\
\hline
\end{tabular}

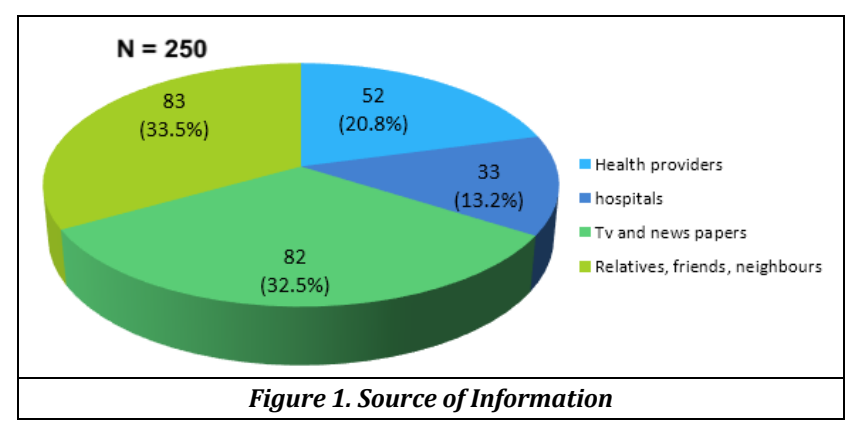

\begin{tabular}{|c|c|c|c|c|c|}
\hline \multirow{9}{*}{ 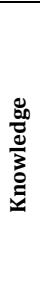 } & & $\begin{array}{c}\text { Education of the head } \\
\text { of the family }\end{array}$ & Yes & No & $\begin{array}{c}\mathbf{p} \\
\text { Value }\end{array}$ \\
\hline & \multirow{2}{*}{$\begin{array}{l}\text { Regarding Mosquito } \\
\text { breeding sites }\end{array}$} & ${ }^{*}$ Group 1 responses & $178(71.2 \%)$ & $4(1.6 \%)$ & \multirow[b]{2}{*}{0.024} \\
\hline & & **Group 2 responses & $66(26.4 \%)$ & $2(0.8 \%)$ & \\
\hline & \multirow{2}{*}{$\begin{array}{l}\text { regarding diseases } \\
\text { spread by mosquitos }\end{array}$} & ${ }^{*}$ Group 1 responses & $182(72.8 \%)$ & $10(4 \%)$ & \multirow{2}{*}{0.005} \\
\hline & & ${ }^{* *}$ Group 2 responses & $43(17.2 \%)$ & $15(6 \%)$ & \\
\hline & \multirow{2}{*}{$\begin{array}{l}\text { regarding symptoms of } \\
\text { mosquito borne diseases }\end{array}$} & ${ }^{*}$ Group 1 responses & $180(72 \%)$ & $21(8.4 \%)$ & \multirow{2}{*}{0.25} \\
\hline & & ${ }^{* *}$ Group 2 responses & $41(16.4 \%)$ & $8(3.2 \%)$ & \\
\hline & \multirow{2}{*}{$\begin{array}{l}\text { Regarding preventive } \\
\text { measures to control } \\
\text { mosquitos }\end{array}$} & ${ }^{*}$ Group 1 responses & $178(71.2 \%)$ & $23(9.2 \%)$ & \multirow{2}{*}{0.5} \\
\hline & & ${ }^{* *}$ Group 2 responses & $45(18 \%)$ & $4(1.6 \%)$ & \\
\hline \multirow{4}{*}{$\underset{\mathscr{U}}{\mathscr{U}}$} & \multirow{2}{*}{$\begin{array}{l}\text { Personal protective } \\
\text { measures }\end{array}$} & ${ }^{*}$ Group 1 responses & $\begin{array}{c}187 \\
(74.8 \%)\end{array}$ & $14(5.6 \%)$ & \multirow[t]{2}{*}{0.014} \\
\hline & & ${ }^{* *}$ Group 2 responses & $41(16.4 \%)$ & $8(3.2 \%)$ & \\
\hline & \multirow{2}{*}{ Anti-larval measures } & ${ }^{*}$ Group 1 responses & $34(13.6 \%)$ & $\begin{array}{c}132 \\
(52.8 \%) \\
\end{array}$ & \multirow{2}{*}{0.001} \\
\hline & & ${ }^{* *}$ Group 2 responses & $46(18.4 \%)$ & $\begin{array}{c}38 \\
(15.2 \%)\end{array}$ & \\
\hline \multicolumn{6}{|c|}{$\begin{array}{l}\text { Table 4. Knowledge and Practice Measures vs Education of } \\
\text { Head of the Family }\end{array}$} \\
\hline \multicolumn{6}{|c|}{$\begin{array}{l}{ }^{*} \text { Group } 1 \text { Responses }=\text { Responses of people whose Head of the family are illiterates } \\
\text { and primary education. }{ }^{* *} \text { Group } 2 \text { Responses = Responses of people whose Head of } \\
\text { the family had completed secondary education and above. }\end{array}$} \\
\hline
\end{tabular}

\begin{tabular}{|c|c|c|c|c|c|}
\hline \multirow{9}{*}{ 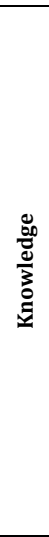 } & & $\begin{array}{c}\text { Socio } \\
\text { Economic } \\
\text { Status }\end{array}$ & Yes & No & $\begin{array}{c}\text { p } \\
\text { Value }\end{array}$ \\
\hline & \multirow{2}{*}{$\begin{array}{c}\text { Regarding } \\
\text { Mosquito breeding sites }\end{array}$} & $\begin{array}{l}{ }^{*} \text { Group } 1 \\
\text { responses }\end{array}$ & $170(68 \%)$ & $2(0.8 \%)$ & \multirow{2}{*}{0.87} \\
\hline & & $\begin{array}{l}{ }^{* *} \text { Group } 2 \\
\text { responses }\end{array}$ & $74(29.6 \%)$ & $4(1.6 \%)$ & \\
\hline & \multirow{2}{*}{$\begin{array}{l}\text { regarding diseases } \\
\text { spread by mosquitos }\end{array}$} & $\begin{array}{l}{ }^{*} \text { Group } 1 \\
\text { responses }\end{array}$ & $159(63.6 \%)$ & $15(6 \%)$ & \multirow{2}{*}{0.27} \\
\hline & & $\begin{array}{l}* * \text { Group } 2 \\
\text { responses }\end{array}$ & $66(26.4 \%)$ & $10(4 \%)$ & \\
\hline & \multirow{2}{*}{$\begin{array}{l}\text { regarding symptoms of } \\
\text { mosquito borne diseases }\end{array}$} & $\begin{array}{l}{ }^{*} \text { Group } 1 \\
\text { responses }\end{array}$ & $153(61.2 \%)$ & $21(8.4 \%)$ & \multirow{2}{*}{0.72} \\
\hline & & $\begin{array}{l}{ }^{* *} \text { Group } 2 \\
\text { responses }\end{array}$ & $68(27.2 \%)$ & $8(3.2 \%)$ & \\
\hline & \multirow{2}{*}{$\begin{array}{l}\text { Regarding preventive } \\
\text { measures to control } \\
\text { mosquitos }\end{array}$} & $\begin{array}{l}{ }^{*} \text { Group } 1 \\
\text { responses }\end{array}$ & $159(63.6 \%)$ & $15(6 \%)$ & \multirow{2}{*}{0.09} \\
\hline & & $\begin{array}{l}{ }^{* *} \text { Group } 2 \\
\text { responses }\end{array}$ & $64(25.6 \%)$ & $12(4.8 \%)$ & \\
\hline \multirow{4}{*}{$\stackrel{\mathscr{U}}{\mathscr{U}}$} & \multirow{2}{*}{$\begin{array}{l}\text { Personal protective } \\
\text { measures }\end{array}$} & $\begin{array}{l}{ }^{*} \text { Group } 1 \\
\text { responses }\end{array}$ & $160(64 \%)$ & $4((5.6 \%)$ & \multirow{2}{*}{0.5} \\
\hline & & $\begin{array}{l}{ }^{* *} \text { Group } 2 \\
\text { responses }\end{array}$ & $68(27.2 \%)$ & $8(3.2 \%)$ & \\
\hline & \multirow{2}{*}{ Anti-larval measures } & $\begin{array}{l}* \text { Group } 1 \\
\text { responses }\end{array}$ & $52(20.8 \%)$ & $144(57.6 \%)$ & \multirow[b]{2}{*}{0.00} \\
\hline & & $\begin{array}{l}{ }^{* *} \text { Group } 2 \\
\text { responses }\end{array}$ & $28(11.2 \%)$ & $26(10.4 \%)$ & \\
\hline \multicolumn{6}{|c|}{ Table 5. Knowledge and Practice Methods Vs Socio Economic Status } \\
\hline \multicolumn{6}{|c|}{$\begin{array}{l}{ }^{*} \text { Group } 1 \text { Responses = Responses given by people belonging to upper lower class. } \\
{ }^{* *} \text { Group } 2 \text { Responses = Responses given by people belonging to lower class. }\end{array}$} \\
\hline
\end{tabular}

\section{DISCUSSION}

The present community based observational study assessed the knowledge and practices regarding VBDs and their prevention in the rural health and training center region of Guntur medical college, Guntur district. The study revealed that knowledge regarding VBDs like Dengue $(29.7 \%)$ and Malaria (44.8\%) was fair in the study participants. However, Chikungunya was named by only $14.1 \%$. The findings are similar to that found in a study by Boratne et al. [8] in 2010 in peri-urban areas of Puducherry where nearly 57\% of the study population was aware about malaria while the knowledge about dengue was just 19\%. A study in Rajkot in 2011 also revealed similar knowledge about VBDs with only $62 \%$ being aware of malaria. These findings show low perception about risk of mosquitoes as a cause of morbidity and mortality, by the study participants. Thus, the study emphasizes the need for intensification of health education regarding VBDs as the prevention of BDs through better knowledge and knowledge is the appropriate way to keep the disease away.[9] The most common source of information about MBDs and their prevention were family and friends followed by television. This finding is in contrast to the results found in other study where television was reported as the most common source.[8] Health-care professionals as source of information were reported by few only which points towards the low participation by doctors and paramedical staff in spreading Knowledge regarding MBDs. Though majority $(81 \%)$ of respondents felt that anti-malarial activities (Fogging) were being undertaken by municipality, but at the same time $85 \%$ of them found that grossly inadequate and irregular. Thus, there is a need for strengthening of efforts for control of MBDs at community level. Practice of using PPMs against mosquitoes was quite high among study subjects (93.6\%). Similar observations were noted in study performed in 300 households of Vadodra District in Gujarat where $97 \%$ of the participants were using at least some kind of the PPMs.(10) A study performed in rural, semi-rural and bordering areas of East Delhi showed the use of PPMs to be nearly $100 \%$.(11) Thus, there is evidently varying practices against mosquito bites from place-to-place. Mosquito coils followed by bed nets, liquid vaporizers were the most common PPMs used in the current study. Studies done in South India, $(8,12)$ found a similar pattern of use of PPMs.

\section{CONCLUSIONS}

There is a gap between the knowledge regarding VBD (Vector Borne Diseases) and practice of vector control among the respondents. This can be decreased by BCC (Behavioural Change Communication) among people regarding preventing the vector borne diseases by using simple protective measures like using bed nets or mosquito repellent coils, by repeated IEC, information education, and communication by health workers. 


\section{ACKNOWLEDGEMENT}

I am grateful to my study subjects who participated in the study to carry out this research work.

\section{REFERENCES}

[1] World Health Organization. A global brief on vectorborne diseases. Geneva: World Health Organization (WHO) 2014. http://www.who.int/campaigns/worldhealth-day/2014/global-brief/en/

[2] National Programme for Prevention and Control of Vector Borne Diseases: Malaria-Magnitude of Problem. 2012. [Accessed on 2012 Dec 25].

[3] Patel AB, Rathod H, Shah P, et al. Perceptions regarding mosquito borne diseases in an urban area of Rajkot city. Natl J Med Res 2011;1(2):45-7.

[4] Erlanger TE, Keiser J, Utzinger J. Effect of dengue vector control interventions on entomological parameters in developing countries: a systematic review and metaanalysis. Med Vet Entomol 2008;22(3):203-21.

[5] Arunachalam N, Tana S, Espino F, et al. Eco-bio-social determinants of dengue vector breeding: a multicountry study in urban and periurban Asia. Bull World Health Organ 2010;88(3):173-84.

[6] Castro M, Sánchez L, Pérez D, et al. A community empowerment strategy embedded in a routine dengue vector control programme: a cluster randomised controlled trial. Trans $\mathrm{R}$ Soc Trop Med Hyg 2012;106(5):315-21.

[7] Andersson N, Nava-Aguilera E, Arosteguí J, et al. Evidence based community mobilization for dengue prevention in Nicaragua and Mexico (Camino Verde, the Green Way): cluster randomized controlled trial. BMJ 2015;351:h3267.

[8] Boratne AV, Datta SS, Singh Z, et al. Attitude and practices regarding mosquito borne diseases and sociodemographic determinants for use of personal protection methods among adults in coastal Pondicherry. Ind J Med Special 2010;1(2):91-6.

[9] Klein RE, Weller SC, Zeissig R, et al. Knowledge, beliefs and practices in relation to malaria transmission and vector control in Guatemala. Am J Trop Med Hyg 1995;52(5):383-8.

[10] Pandit N, Patel Y, Bhavsar B. Awareness and practice about preventive method against mosquito bite in Gujarat. Health Line 2010;1(1):16-20.

[11] Tyagi P, Roy A, Malhotra MS. Knowledge, awareness and practices towards malaria in communities of rural, semirural and bordering areas of east Delhi (India). J Vector Borne Dis 2005;42(1):30-5.

[12] Snehalatha KS, Ramaiah KD, VijayKumar KN, et al. The mosquito problem and type and costs of personal protection measures used in rural and urban communities in Pondicherry region, South India. Acta Trop 